\title{
Walter E. Beach, Warren E. Miller, and Jewel Prestage to Receive 1998 Goodnow Awards
}

Walter E. Beach, Warren E. Miller, and Jewel Prestage will receive the 1998 Frank J. Goodnow Awards for distinguished service to the profession and the American Political Science Association at the 1998 Honors Reception, Wednesday, September 2, as part of the APSA Annual Meeting in Boston.

Walter Beach will receive the award in recognition for his tireless contributions to the work of the national association and his role in the development of the Southern Political Science Association. An unflagging good citizen and fund raiser for political science, Beach developed the carly international activities of the Association, directed the Congressional Fellowship Program, and served as the second editor of $P S$ during his tenure as Assistant Director of APSA. The National Capital Area Political Science Association has stayed an active force in the Washington, DC political science community as a result of Beach's work over several decades as its Secretary-Treasurer. Many other organizations headquartered in the nation's capital, like the International Eye Foundation and the United Nations Association of the National Capital Area, have been strengthened by Beach's leadership. Beach's commitment to higher education is evident in his years of service as a trustee for both Dickinson College and Mount Vernon College.

Warren Miller will be honored not

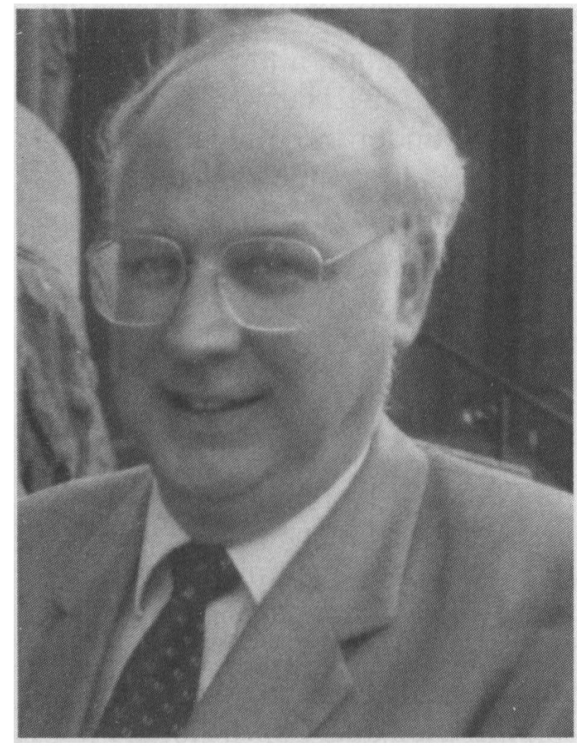

Walter E. Beach only for his contributions to the study of electoral politics, but also for his 47 years of leadership at the Institute for Social Research and his 27 years of direction of the American National Election Studies. As the first executive director of the Inter-University Consortium for Political and Social Research, Warren Miller played a vital role in creating, and facilitating the use of, the largest archive of quantitative social science data in the United States. Miller's service to the Association through committee work and as president has strengthened the profession, and his unwavering commitment to advancing the understanding of electoral politics has enhanced the discipline.

Jewel Prestage will be commended for her lifetime commitment to the education of African Americans and her crucial role in the creation of the Ralph Bunche Summer Institute, a critical element in APSA's efforts to increase minority representation in graduate study and political science faculties. An early African-American recipient of a $\mathrm{Ph} . \mathrm{D}$. in political science, Jewel Prestage has been a mentor to and model for generations of political science students. Through her service on numerous APSA committees, her work to shape the evolving political science curricula, and her years as a professor and dean at Southern University and Prairie View A\&M Univer-

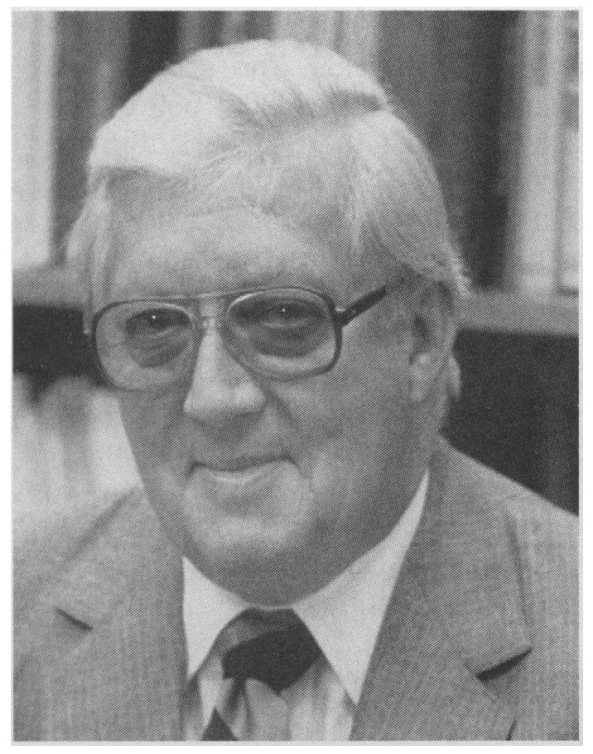

Warren E. Miller sity, Prestage has had a significant impact on the profession.

The APSA Council established the Frank J. Goodnow Awards in 1996 to honor the contributions of individuals to both the development of the political science profession and the building of the Association. Frank J. Goodnow, the Association's first president, exemplified the public service and volunteerism that this award represents. $\mathrm{He}$ was the first of many who voluntarily contributed an extraordinary amount of time, energy, and attention to building a dynamic learned profession. The Goodnow Awards were given for the first time at the 1997 Annual Meeting and presented to Pendleton Herring, Roberta Sigel, Max Kampelman, and Eugene Eidenberg.

Nominations for the 1999 Goodnow Awards, to be presented at the 95th Annual Meeting in Atlanta, September 2-5, 1999, are being accepted until November 1, 1998. The Endowments Committee will select nominees and APSA's Administrative Committee will name the winners. To submit nominations, including self-nominations, please send a letter and a copy of the nominee's curriculum vita to Goodnow Awards, c/o Laura Barrantes, APSA, 1527 New Hampshire Avenue, NW, Washington, DC 20036-1206. Questions about the nomination process should be directed to Laura Barrantes at (202) 483-2512 or lbarrantes@ apsanet.org.

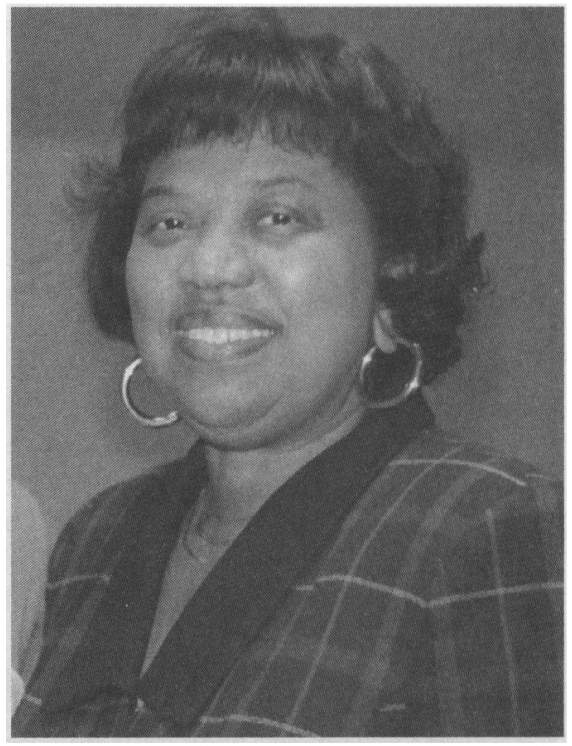

Jewel Prestage 


\section{Centennial Campaign Update}

\section{Be Bullish on the Centennial Campaign}

The performance of the stock market has led many Americans to give away appreciated securities contributing to a $7.5 \%$ increase in 1997 charitable giving, as reported by Giving USA and the Chronicle of Philanthropy. The federal tax code provides a special incentive-over and above the usual charitable deduction-to encourage contributions of this sort to nonprofit organizations like APSA.

As you think about a gift to the Centen-

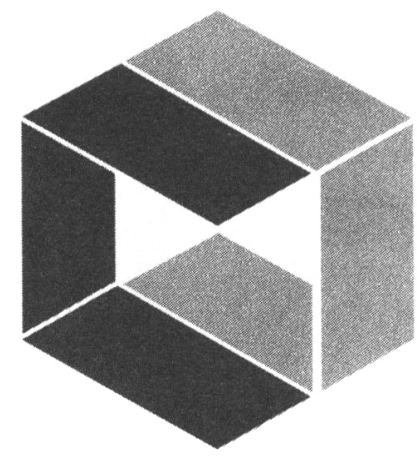
nial Campaign, you might consider taking advantage of this special incentive. Specifically, if you have held securities for at least 12 months and then contribute them to APSA, you can avoid capital gains taxes on the appreciated portion of the stock, qualify for a tax deduction equal to the stock's full market value, and contribute to the Association's Centennial Campaign at a higher level than you anticipated.

The case of Professor Largess illustrates how you can avoid a tax loss and gain a charitable deduction by giving appreciated stock to the Centennial Campaign. Professor Largess, by no means a person of great wealth, has managed over the course of a challenging career to build a modest portfolio of stocks and bonds. Committed to preserving opportunities that he enjoyed for the next generation of political scientists, Professor Largess decided to give the Centennial Campaign 200 shares of Accessinc, an emerging electronics firm trading at $\$ 50$ per share. His cost basis for the stock purchased in 1980 was $\$ 5.00$ per share, creating a potential capital gain liability of $\$ 1800$. By giving the 200 shares to the Centennial Campaign, Professor Largess avoided paying the $\$ 1800$ capital gains tax, was eligible for a charitable deduction for the full $\$ 10,000$ value of his gift, gave the Campaign $\$ 1800$ more than he might otherwise have been able to, and joined the 2003 Circle of the Centennial Campaign.

Transferring gifts of stock to the Centennial Campaign is a simple process. If your banker, broker, or trust officer holds the stock certificates, ask them to transfer the stock to APSA. The Association's agent is Merrill Lynch, $1850 \mathrm{~K}$ Street, NW, Suite 700, Washington, DC 20006. The Association's account number is 749-04H69. The account manager is Ms. Haley Kaufman, who can be reached at (202) 659-6070.

The procedure is slightly different if you hold the stock certificates yourself. In that case, send the certificates to APSA by certified mail. The certificates should not be signed or annotated. Include a cover letter with the certificates in which you name APSA as the recipient of the gift. In a separate letter, send a stock power, also by certified mail with only your signature and, if applicable, your spouse's signature. The signatures should be exactly as your name(s) appear on the stock certificates. Send both to: The Centennial Campaign, American Political Science Association, 1527 New Hampshire Avenue, NW, Washington, DC 20036-1206.

If you have any questions regarding gifts of securities to the Centennial Campaign, please contact Campaign Director Rob Hauck at (202) 483-2512 or via email at rhauck@apsanet.org.

\section{APSA Receives Grant from The Andrew W. Mellon Foundation}

The Andrew W. Mellon Foundation has awarded APSA a $\$ 311,000$ grant to develop PROceedings: Political Research Online and evaluate its use and economic flexibility. The grant will fund the PROceedings project for a three-year period. The project grant is the second that APSA has received from the Mellon Foundation to fund PROceedings. In late 1997, the Mellon Foundation awarded the Association a small planning grant that allowed the Association to develop the PROceedings project proposal and seek outide evaluations of the planned project.

The PROceedings project was designed to evaluate the demand for and use of a collection of fresh scholarship in the discipline and to examine the application of electronic communication to such an endeavor. In addition to monitoring the use of and demand for PROceedings, the three-year period funded by the grant will give APSA the opportunity to explore various funding options for making PROceedings self-sustaining. The Association will explore a number of options, including: submission fees; including the use of PROceedings in the cost of meeting registration; including use of PROceedings as a benefit of membership; charging for use of PROceedings on a pay-per-paper basis; and selling an archival version of each year's collection to libraries.

PROceedings, a joint project of APSA and the Harvard University Library under the direction of William J. Ball of the College of New Jersey, debuted at the 1997 meeting in Washington, DC. The PROceedings web site (http://pro. harvard. edu) features a fully browsable Annual Meeting Program as well as a search engine for performing keyword searches. The 1998 collection of Annual Meeting papers became available on August 18, 1998. All 1998 paper authors were invited to submit their papers to the collection, which will remain online for one year. The PROceedings web site will be on display in the Panel Paper Room throughout the Boston meeting.

\section{Celebrating the Past by Investing in the Future}

